\title{
The Application of TAM on Utilization of Financial Information Technology in South Sulawesi
}

\author{
$\operatorname{Ibrahim}^{1 *} \&$ Sri Rahayu Syah ${ }^{2}$
}

\author{
${ }^{1}$ National Informatics Polytechnic, Makassar, Indonesia \\ ${ }^{2}$ National Informatics Polytechnic, Makassar, Indonesia \\ *Corresponding author. Email: ibrahimranreng2018@gmail.com
}

\begin{abstract}
In the industrial revolution era and information technology advancement, TAM must align with development and progress. TAM is believed able to fulfill the needs of relevant technology users. This study aims to analyze the factors that influence the utilization of regional financial information systems in OPD of South Sulawesi Province. This research method applied a quantitative approach, and the data is collected from 147 users in 49 provincial OPD in South Sulawesi using a questionnaire. The non-probability sampling was used and analyzed using SPSS version 21. Hypothetical test results reveal that perceived usefulness, perceived ease of use, perceived security, perceived reliability, relative advantages, compatibility, service quality, self-efficacy, work facilitation, cost reduction, and time saving have a positive and significant effect on the intention to use SIPKD, while, energy saving has no effect on the intention to use SIPKD. The results of this study show the importance of creating a financial information system that is easy to use and relevant for any users to improve the performance in serving the public.
\end{abstract}

Keywords: TAM, Intention to use SIPKD, Perceived Usefulness, Perceived ease of use, USTAM.

\section{INTRODUCTION}

TAM is demanded in line with the developments in the industrial revolution era and the information technology advancement. Therefore, TAM also undergoes construction modifications so that it can fulfill technological developments and advancements. In technology acceptance, this TAM model requires collaboration with other theories to study and measure the users' perception of relevant technologies at present.

Sepasgozar et al. (2019) reveal a technology acceptance model that combines the TAM theory model and the SCT (Social Cognitive Theories), which is called the Urban Society Technology Acceptance Model (USTAM). This model can help urban communities in developing countries in selecting technolo- gies. Moreover, this model can convince all decision-makers and the planning part to adopt and receive new technologies before going to the public.

Regional financial information systems support is required to improve public services and create transparency and accountabilitybased good governance. Many regulations governing financial management, ranging from central to regional, require a financial information system based on efficiency, economy, effectiveness, transparency, accountability, and auditable. In South Sulawesi, there are 24 (twenty-four) districts/cities where 17 (seventeen) of them use the new SIPKD application.

Based on the Ministry of Home Affairs 2010, the Regional Financial Management Information Systems (SIPKD) is an integrated application used as a tool for local govern- 
ments to improve the effectiveness of regional financial management based on the principles of efficiency, economy, effectiveness, transparency, accountable, and auditable.

From 2003 to 2018, through a systematic search using EBSCO Discovery Service to develop TAM review literature form, Granić and Marangunić (2019) state that 71 relevant studies have been identified and the studies prove that two TAM constructions influence the interest of technology utilization.

One of the motivations underlying this research is to assess the theory or model of USTAM, developed by Sepasgozar et al. as the utilization of the SIPKD technology system in Regional Apparatus Organization (OPD) South Sulawesi that is still rarely studied. Another reason is finding out the factors that influence SIPKD utilization in OPD of South Sulawesi province.

\subsection{Urban Security Technology Acceptance Model (USTAM)}

This research is conducted to reveal the factors that influence the intention to use the SIPKD in the regional government of South Sulawesi. The researchers use a model introduced by Sepasgozar et al. in order to reveal these factors. This model is called Urban Security Technology Acceptance Model (USTAM). USTAM hypothesizes that the critical factors related to technology include Self-Efficacy, Operations, Work Facilitation, Relative Advantages, and Compatibility. USTAM is a valuable model for predicting technology acceptance in Smart city implementations.

The model presented by USTAM can achieve goals in selecting the right technology that is useful for some areas with different cultural identities and characteristics and the one who wants to start a smart city strategy. Therefore, the authors think it becomes relevant if the USTAM Model is applied to analyze the factors that influence the utilization of SIPKD in the OPD of the South-Sulawesi government.

\subsection{Technology Acceptance Model (TAM)}

TAM model is a theory that intends to explain that a person's perception of something will determine the attitude and behavior of that person towards the acceptance of technology (Jati and Laksito 2012). Various literature reveals the development of TAM models, which aims to understand and explain the main factors/keys of the user toward the acceptance of technology. Davis (1989) argues that the acceptance level of information technology is determined by external variables, namely complexity using the internet.

Chau and $\mathrm{Hu}$ (2001) in Mun and Hwang (2003) believe that the development of technology acceptance model literature provides six variable keys: Perceived Security, Relative Advantage, Perceived Ease of use, Perceived Usefulness, Compatibility, and Reliability, which are considered the most influential to the intention to utilize technology. Ribbink et al. (2004) assume that service quality is the most important variable used in measuring continuous technology acceptance and the results significantly affect the technology acceptance.

\section{RESEARCH METHODS}

\subsection{Research Design}

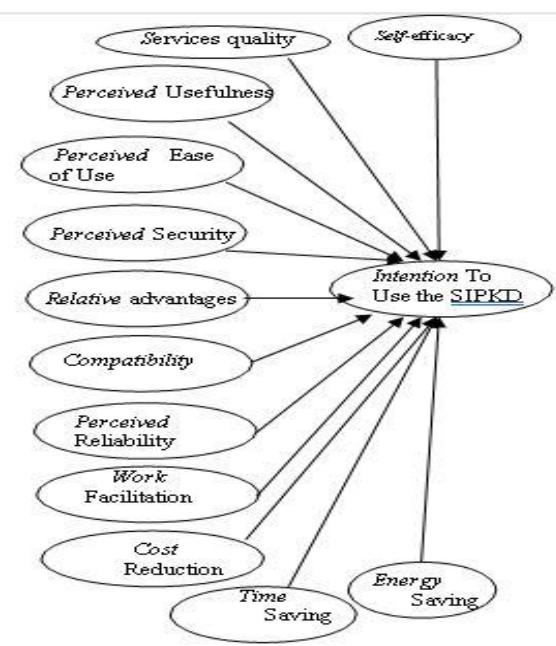

Figure 1. Research Design 


$$
\begin{aligned}
& \quad Y=\alpha+\beta_{1} X_{1}+\beta_{2} X_{2}+\beta_{3} X_{3}+\beta_{4} X_{4} \\
& \quad+\beta_{5} X_{5}+\beta_{6} X_{6}+\beta_{7} X_{7}+\beta_{8} X_{8} \\
& +\beta_{9} X_{9}+\beta_{10} X_{10}+\beta_{11} X_{11}+\beta_{12} X_{12} \\
& +\mu \\
& \text { Where } \\
& \text { X1 }=\text { Perceived Usefulness } \\
& \text { X2 }=\text { Perceived ease of use } \\
& \text { X3 }=\text { Perceived Security } \\
& \text { X4 }=\text { Relative Advantages } \\
& \text { X5 }=\text { Compatibility } \\
& \text { X6 }=\text { Perceived Reliability } \\
& \text { X7 }=\text { Service Quality } \\
& \text { X8 }=\text { Self-efficacy } \\
& \text { X9 }=\text { Work Facilitation } \\
& \text { X10 }=\text { Cost Reduction } \\
& \text { X11 }=\text { Energy Saving } \\
& \text { X12 }=\text { Time Saving } \\
& \mathrm{Y}=\text { Intention to Use the SIPKD }
\end{aligned}
$$

\subsection{Research Methodology}

This research applied a quantitative approach to determine the factors that influence SIPKD utilization in OPD of South Sulawesi Province. This research was conducted in the working area of the Provincial Government of South Sulawesi.

Primary data collection was conducted by doing a direct survey method using questionnaire media. The data were analyzed through linear regression techniques using (SPSS) tools.

\section{RESULTS AND DISCUSSIONS}

This research is conducted to reveal the factors that influence the intention to utilize the SIPKD. The data was collected by distributing non-probability sampling questionnaires to forty-nine OPD in Makassar, South Sulawesi. There were 147 questionnaires distributed, and 140 questionnaires were returned, but the questionnaires processed were only 133 .
Table 1. Research Results

\begin{tabular}{lrrlll}
\hline $\begin{array}{l}\text { Influence Varia- } \\
\text { ble X to } Y\end{array}$ & $\begin{array}{l}\text { Coef- } \\
\text { ficient }\end{array}$ & $\mathrm{T}$ & Sig. & $\begin{array}{l}\text { Descrip- } \\
\text { tion }\end{array}$ \\
\hline (X1) & $\mathrm{Y}$ & 0.174 & 2.240 & 0.027 & Accepted \\
(X2) & $\mathrm{Y}$ & 0.287 & 4.296 & 0.000 & Accepted \\
(X3) & $\mathrm{Y}$ & 0.176 & 2.094 & 0.038 & Accepted \\
(X4) & $\mathrm{Y}$ & -0.320 & -2.712 & 0.008 & Accepted \\
(X5) & $\mathrm{Y}$ & -0.294 & -3.536 & 0.001 & Accepted \\
(X6) & $\mathrm{Y}$ & 0.143 & 1.990 & 0.049 & Accepted \\
(X7) & $\mathrm{Y}$ & 0.271 & 2.418 & 0.017 & Accepted \\
(X8) & $\mathrm{Y}$ & 0.182 & 2.281 & 0.024 & Accepted \\
(X9) & $\mathrm{Y}$ & 0.213 & 2.097 & 0.038 & Accepted \\
(X10) & $\mathrm{Y}$ & 0.158 & 2.419 & 0.017 & Accepted \\
(X11) & $\mathrm{Y}$ & 0.036 & 0.305 & 0.761 & Rejected \\
(X12) & $\mathrm{Y}$ & 0.121 & 2.265 & 0.025 & Accepted \\
\hline
\end{tabular}

The Significant Above $\alpha=5 \% ; \mathrm{F}=53.421 ; \mathrm{R}^{2}=0.842$; $\mathrm{N}=133$

Table 1 exibites that perceived usefulness shows significant results, which means that the SIPKD application is very beneficial for users in improving the users' performance. These results are supported by Sepasgozar et al. (2019); Kabbiri et al. (2018) research.

In Table 1, the influence of perceived ease of use also shows significant results. This means that the SIPKD application is easy to use, and the application is believed can improve the user's performance. These results are supported by Sepasgozar et al. 2019); Kabbiri et al. (2018) research.

The influence of perceived security on Table 1 also shows significant results. This means that the SIPKD application is very safe to use and the application is

believed can improve its users' activity performance. These results are supported by Sepasgozar et al. (2019); Denaputri and Usman's (2019) research.

The significant result is also shown in Table 1 due to the influence of relative advantages. This signifies that many users believe that the SIPKD application is the best technological innovation and that the application is believed to improve the users' performance. These results are supported by Sepasgozar et al. (2019); Al-Rahmi et al.'s (2019) research.

Still, in Table 1, the influence of compatibility 
also shows significant results. This means that the SIPKD application can convince the users that the application fits all users who sometimes still have activities outside office hours and the application is believed can improve the users' performance. These results are supported by Sepasgozar et al. (2019); Setiawan (2018) research.

Perceived reliability influence on Table 1 shows significant results. This means that the SIPKD application can convince the users that the application is very reliable and that the application can improve the users' performance. These results are supported by Sepasgozar et al. (2019); Wahyuni (2018) research. Significant results are also shown in Table 1 related to the influence of service quality. This means that the SIPKD application provides better service quality for users and the application is believed can improve the users' performance. These results are supported by Sepasgozar et al. (2019); Ribbink et al. (2004) research.

Table 1 related to the influence of selfefficacy shows significant results. This means that the SIPKD application convinces users to have better ability and that the application can improve the users' performance. These results are supported by Sepasgozar et al. (2019); Wicaksono and Mispiyanti (2019) research.

The influence of work facilitation in Table 1 shows significant results. This means that the SIPKD application can simplify the users' tasks and the application is believed can improve the users' performance. These results are supported by Sepasgozar et al. (2019); Farabi (2016).

In Table 1, the influence of cost reduction shows significant results. This means that the SIPKD application can reduce inefficient costs and the application is believed can improve the users' performance. These results are supported by Sepasgozar et al. (2019); Ambarwati and Isnugroho (2018); and Fauzia (2018) research.

The influence of energy-saving in Table 1 shows insignificant results. This means that cost-effective electricity is not the factor in- fluencing a person's decision to use the SIPKD application. These results are supported by Sepasgozar et al.'s (2019) research.

Table 1 exhibits that the influence of timesaving shows significant results in Table 1. This means that the SIPKD application can save time and the application is believed to improve the users' performance. These results are supported by Sepasgozar et al. (2019); Ambarwati and Isnugroho's (2018) research.

\section{CONCLUSION}

This study reveals practical implications that cost-effective electricity is not the main factor that affects an individual's interest in using information technology systems. This means that the problem of electricity saving is not the most interesting problem for users in using the internet system. Because the results will undoubtedly be different if they do it manually, this result also has implications in designing applications in the USTAM model to help to utilize the SIPKD. This electricity saving has excellent potential concerning the expense, so it becomes fascinating to study further to get significant results.

A limitation of this study was that all respondents were affected by the Covid-19 pandemic. Another limitation is the low questionnaire return rate, as the questionnaires were distributed via email.

\section{REFERENCES}

Al-Rahmi, W.M., Yahaya, N., Aldraiweesh, A.A., Alamri, M.M., Aljarboa, N.A., Alturki, U., Aljeraiwi, A. 2019. "Integrating Technology Acceptance Model with Innovation Diffusion Theory: An Empirical Investigation on Students' Intention to Use E-Learning Systems." IEEE Access 7: 26797-26809.

Ambarwati, S., and Isnugroho, E. 2018. "Pengaruh Perceived Risk, Cost Saving, Dan Time Saving Terhadap Kepuasan Pelanggan Pada Pembelian Tiket Pesawat Online Di Situs Www. Tiket2. Com." Journal of Tourism and Economic 1(1): 10-18. 
Chau, P.Y.K., and Hu, P.J.H. 2001. "Information Technology Acceptance by Individual Professionals: A Model Comparison Approach." Decision sciences, 32(4): 699-719.

Davis, F.D., Dafis, F. 1989. "Perceived Usefulness, Perceived Ease of Use, and User Acceptance of Information Technology." MIS quarterly: 319340.

Denaputri, A., and Usman, O. 2019. Effect of Perceived Trust, Perceived Security, Perceived Usefulness and Perceived Ease of use on Customers' Intention to Use Mobile Payment. SSRN Electronic Journal. doi:10.2139/ssrn.3511632

Farabi, N.A. 2016. Analisis Penerapan Sistem Informasi ZISW Dengan Menggunakan Metode UTAUT. Indonesian Journal on Computer and Information Technology, 1(2): 71-79

Fauzia, R.N. 2018. Analisis Faktor-Faktor Yang Mempengaruhi Penerimaan Social Commerce Di Indonesia. Retrieved from https://dspace.uii.ac.id/bitstream/handle/1234567 89/6499/skripsi refika nurliani fauzia 14312627. Copy.pdf? sequence $=1 \&$ isAllowed=y.

Granić, A., and Marangunić, A. 2019. Technology Acceptance Model in Educational Context: A Systematic Literature Review. British Journal of Educational Technology 50(5): 2572-2593.

Jati, N. J., \& Laksito, H. (2012). ANALISIS FAKTOR-FAKTOR YANG MEMPENGARUHI MINAT PEMANFAATAN DAN PENGGUNAAN SISTEM E-TICKET (Studi Empiris pada Biro Perjalanan di Kota Semarang). Diponegoro Journal of Accounting, 1(1): 511-524.

Kabbiri, R., Dora, M., Kumar, V., Elepu, G., \& Gellynck, X. 2018. Mobile Phone Adoption in AgriFood Sector: Are Farmers in Sub-Saharan Africa Connected?. Technological Forecasting and Social Change 131: 253-61.

Kementerian Dalam Negeri. 2010. Petunjuk Pelaksanaan SIPKD,. Jakarta: www.kementriandalamnegri.go.id.

Mun, Y.Y., and Hwang,Y. 2003. Predicting the Use of Web-Based Information Systems: Self-Efficacy, Enjoyment, Learning Goal Orientation, and the Technology Acceptance Model. International journal of human-computer studies 59(4): 431-49.

Ribbink, D., Riel, A.C.R.V., Liljander, V., and Streukens, S. 2004. Comfort Your Online Customer: Quality, Trust and Loyalty on the Internet. Managing Service Quality: An International Journal, 14: 446-456.

Sepasgozar, S., Hawken, S., Sargolzaei, S., and Foroozanfa, M. 2019. Implementing Citizen Centric Technology in Developing Smart Cities: A Model for Predicting the Acceptance of Urban Technolo- gies. Technological Forecasting and Social Change, 142(1): 105-116.

Setiawan, Y.Ary. 2018. "Pengaruh Kegunaan, Kesesuaian, Keuntungan Relatif, Motivasi Hedonik Dan Kebiasaan Terhadap Penggunaan mobile Banking BCA Surabaya Yang Dimediasi Intensi Menggunakan.'Skripsi Sekolah Tinggi Ilmu Ekonomi Perbanas.

Wahyuni, T. 2018. Why Should MSMEs Adopt Accounting Application with Cloud Computing? The Reality of MSMEs in Depok, West Java. Proceedings of the KnE SocialSciences: 1399-1414.

Wicaksono, R., and Mispiyanti, M. 2019.Faktor-Faktor Yang Mempengaruhi Kepuasan Pengguna Sistem Informasi Pengelolaan Keuangan Daerah (SIPKD) Pada Kalangan Pegawai Negeri Sipil. InFestasi (Jurnal Bisnis dan Akuntansi), 15(2): 177-90. 